\title{
Boron Desorption Kinetic in Calcareous Soils
}

\author{
Baydaa H. A. Al-Ameri ${ }^{1}$ \\ ${ }^{1}$ Soil \& Water Resources Research Center, Agriculture Research Directorate, Ministry of Science and \\ Technology, Baghdad, Iraq \\ Correspondence: Baydaa H. A. Al-Ameri, Soil \& Water Resources Research Center, Agriculture Research \\ Directorate, Ministry of Science and Technology, Baghdad, Iraq. E-mail: Baydaa.2012@yahoo.com
}

Received: January 9, 2019

Accepted: February 14, $2019 \quad$ Online Published: April 15, 2019

doi:10.5539/jas.v11n5p525

URL: https://doi.org/10.5539/jas.v11n5p525

\begin{abstract}
Boron release (desorption) is one of the important factors use in estimating fertilizers use efficiency and management of boron in agricultural soils and correlation soil properties with it availability to plant. Chemical kinetics for boron desorption experiment was carried out of boric acid (source for boron fertilizer) under controlled conditions in three calcareous soils (clay, loamy and sandy loam) from central Iraq at three temperatures (278, 298 and 308 Kelvin), by using six mathematical and empirical equations viz. Zero order, First order, Second order, Parabolic diffusion, Power function and Elovich equation were used to study kinetic behavior of boron in calcareous soils.

Elovich equation was the best for predication and describing boron released with highest correlation $r=0.942$ and $t$ value (9.004), and lowest SE.e (0.530) where boron release rate constant $(\mathrm{K})$ was positively correlated with temperature $(\mathrm{r}=0.978)$. Released rate constant $(\mathrm{K})$ was increased from 0.329 to $0.561 \mathrm{hrs}^{-1}$ as increasing incubation temperature from 278 to $308 \mathrm{~K}$. Soils texture effect in boron release activation energy (Ea) in three soils under study. The overall average of boron release activation energy of three soils was 15.284 and the highest was 20.923 in clay soil and the lowest amount was 4.596 in sandy loam while loamy soil gave $20.332 \mathrm{KJ}$ $\mathrm{mol}^{-1}$.
\end{abstract}

Keywords: boron release, kinetic models, texture

\section{Introduction}

Growth, development and completion life of most economic plants depends mainly on the availability and release of ions in soil system. Fried and Broeshart (1967) explained that the process of ion interaction in the soil and its transfer to plant root system can be described according to the following equation:

$$
\mathrm{A} \longleftrightarrow \mathrm{B} \longleftrightarrow \mathrm{C}
$$

where, A: amount of ions in soil solution; B: amount of adsorption ion; C: represents the amount of ion retention in the form of limited and low-solubility compounds.

When equilibrium occurrence between $\mathrm{A}$ and $\mathrm{B}$ is fast reaction and this reaction determines the initial adsorption surface $(t=0)$ while the interaction between the two components (B and C), which is type of forward reaction, is generally slow, because strength bond of ion in component $\mathrm{C}$ is relatively high. Boron quantities in soil solution are usually controlled by adsorption-desorption reactions.

Two types of equations have been used to describe the relationship between path and speed of boron release reactions over time, one of which is based on kinetic chemistry as the Zero-order, First and Second-order equations, and the second is based on natural bases such as Parabolic and empirical as Power function and Elovich (Sparks, 1986). The comparison between the two equations is based on statistical parameters, namely correlation coefficient ( $r$ ), determined coefficient $\left(r^{2}\right)$, SE.e and $t$ value (Al-Ameri, 2001, 2013).

In order to study kinetic behavior of boron in calcareous soil, a laboratory experiment (batch Technic) was conducted under controlled conditions to study the kinetic chemistry of boron release reactions at three different temperatures in three soils from center of Iraq. 


\section{Materials and Methods}

The experiment was conducted to characterize the kinetic behavior of boron with time (using 11 time periods from zero to 720 hour) and temperature 278, 298, and 308 Kelvin implementing different kinetics equations in three calcareous soils from the center of Iraq, chemical and physical soil properties estimate according to Page et al. (1982) (Table 1). For this purpose, $125 \mathrm{gm}$ of plastic pots was used; $100 \mathrm{~g}$ of soil was packed in these pots. Adding of boric acid as a source of boron fertilizer in solution of $20 \mathrm{mg} \mathrm{kg}^{-1}$ solvent in calcium chloride solution ( 0.01 molar) and in the form of Bands. Cover the compost with about $15 \mathrm{gm}$ of soil (1 cm deep). Soil moisture was maintained at $80 \%$ of field capacity during incubation periods of $0,0.5,1.0,2.0,4.0,6.0,24,96,240,480$, 720 hours. Loss of soil moisture was compensated periodically depending on weight throughout the course of the experiment. Samples were taken at the end of each incubation period, dried and sieved with $2.0 \mathrm{~mm}$ sieve. Boron was extracted with hot water according to Berger and Truog (1939) and estimated by ICP (Inductivity Couple Plasma Atomic Emission Spectrometer model ICPE-9000 SHIMADZU).

Table 1. Soil chemical and physical properties

\begin{tabular}{|c|c|c|c|c|}
\hline \multirow{2}{*}{ Property } & \multirow{2}{*}{ Unit } & \multicolumn{3}{|c|}{ Value } \\
\hline & & Clay & Loam & Sandy loam \\
\hline EC 1:1 & $\mathrm{dSm}^{-1}$ & 0.72 & 7.47 & 0.16 \\
\hline $\mathrm{pH} \mathrm{1:1}$ & & 7.50 & 6.82 & 7.69 \\
\hline Calcium carbonite & $\mathrm{g} \mathrm{kg}^{-1} \mathrm{soil}$ & 238.3 & 250.0 & 256.0 \\
\hline Organic mater & & 20.0 & 1.98 & 4.0 \\
\hline $\mathrm{NH}_{4}-\mathrm{N}$ & & 40.88 & 30.92 & 12.32 \\
\hline $\mathrm{NO}_{3}-\mathrm{N}$ & mg N Kg so1l & 14.7 & 10.42 & 7.7 \\
\hline Available-P & $\mathrm{mg} \mathrm{Kg}^{-1}$ soil & 18.21 & 23.51 & 13.29 \\
\hline Available-Ca & & 74.49 & 81.425 & 46.52 \\
\hline Available-Mg & $\mathrm{C}$ mole $+\mathrm{kg}^{-1}$ soil & 5.48 & 5.95 & 1.80 \\
\hline Available-K & & 7.58 & 9.83 & 1.16 \\
\hline Boron (H.W.) & $\mathrm{mg} \mathrm{Kg}^{-1}$ soil & 1.268 & 3.050 & 0.147 \\
\hline Sand & & 162.64 & 428.7 & 755.51 \\
\hline Silt & $\mathrm{g} \mathrm{kg}^{-1}$ soil & 378.03 & 368.7 & 80.16 \\
\hline Clay & & 459.33 & 202.6 & 164.33 \\
\hline Texture & & Clay & Loam & Sandy loam \\
\hline
\end{tabular}

Several kinetic equations based on kinetic chemistry and mathematical and physical equations have been used to describe boron release in the soil system (Chien et al., 1980; Al-Ameri, 2001; 2013):

$>$ Zero order equation: $\mathrm{C}_{\mathrm{t}}=\mathrm{C}_{0}-\mathrm{kt}$

$>$ First order equation: $\mathrm{LnC}_{\mathrm{t}}=\mathrm{LnC}_{0}-\mathrm{kt}$

$>$ Second order equation: $1 / \mathrm{C}_{\mathrm{t}}=1 / \mathrm{C}_{0}+\mathrm{kt}$

$>$ Parabolic diffusion equation: $\mathrm{C}_{\mathrm{t}}=\mathrm{C}_{0}-\mathrm{k} \sqrt{\mathrm{t}}$

> Power function equation: $\mathrm{LnC}_{\mathrm{t}}=\mathrm{LnC}_{0}-\mathrm{kLnt}$

$>$ Elovich equation: $\mathrm{C}_{\mathrm{t}}=\mathrm{C}_{0}-\mathrm{kLnt}$

where, $\mathrm{C}_{\mathrm{t}}$ : boron desorption at $\mathrm{t}>0 ; \mathrm{C}_{0}$ : boron desorption at $\mathrm{t}=0 ; \mathrm{k}$ : Release rate constant; $\mathrm{t}$ : time.

\section{Results and Discussion}

In order to determine relationship between behavior of boron desorption speed reactions with incubation period (reaction time), six equations were used, some of which were based on kinetic chemistry, (Zero, First and Second order) and equations of natural bases, such as Parabolic diffusion equation and mathematical, empirical bases, like Elovich and Power function equation at three temperatures are 5, 25 and $35{ }^{\circ} \mathrm{C}(278,298$ and 308 Kelvin). Some statistical parameters $\left(r, r^{2}\right.$, and $t$ ) and standard error of estimate (SE.e) were used to evaluate the efficiency of these equations in description boron desorption (Tables 2, 3 and 4). 
Results showed (Tables 2, 3, 4; Figure 1) that Elovich equation was the most efficient in describing relationship between boron desorption and reaction time $(\mathrm{t})$ and was significantly at $(\mathrm{P} \leq 0.01)$ in clay, loam and sandy loam soils, with highest correlation coefficient $(0.929,0.923$ and 0.974$)$, respectively and highest value of calculated $t$ (7.291, 7.286 and 12.343) compared with other equations that used in the study. The efficiency of these equations in description boron desorption and evaluation release rate were $0.86,0.85$ and $0.95 \%$ for clay, loam and sandy loam soils respectively. The equations used in this study can be arranged in the following order: Elovich $>$ Power function $>$ Parabolic diffusion $>$ Second order $>$ First order $>$ Zero order.

Table 2. Efficiency of kinetic and experimental equations in describing relationship between boron desorption and time $(\mathrm{n}=11)$ in Clay soil

\begin{tabular}{|c|c|c|c|c|c|c|}
\hline Equation & Mathematical model & Temperature degree & $\mathrm{r}^{* *}$ & $\mathrm{r}^{2}$ & Standard error of estimate SE.e & $\mathrm{t}$ value \\
\hline \multirow{4}{*}{ Zero order } & \multirow{4}{*}{$\mathrm{C}_{\mathrm{t}}=\mathrm{C}_{0}-\mathrm{k}_{\mathrm{t}}$} & 5 & 0.915 & 0.838 & 0.873 & 6.821 \\
\hline & & 25 & 0.776 & 0.602 & 0.751 & 3.687 \\
\hline & & 35 & 0.763 & 0.582 & 1.145 & 3.541 \\
\hline & & Mean & 0.818 & 0.674 & 0.923 & 4.683 \\
\hline \multirow{4}{*}{ First order } & \multirow{4}{*}{$\mathrm{LnC}_{\mathrm{t}}=\mathrm{LnC}_{0}-\mathrm{k}_{\mathrm{t}}$} & 5 & 0.932 & 0.868 & 0.059 & 7.702 \\
\hline & & 25 & 0.803 & 0.645 & 0.052 & 4.039 \\
\hline & & 35 & 0.796 & 0.633 & 0.066 & 3.941 \\
\hline & & Mean & 0.844 & 0.715 & 0.059 & 5.227 \\
\hline \multirow{4}{*}{ Second order } & \multirow{4}{*}{$1 / \mathrm{C}_{\mathrm{t}}=1 / \mathrm{C}_{0}+\mathrm{k}_{\mathrm{t}}$} & 5 & 0.945 & 0.892 & 0.004 & 8.622 \\
\hline & & 25 & 0.828 & 0.686 & 0.004 & 4.431 \\
\hline & & 35 & 0.826 & 0.682 & 0.004 & 4.397 \\
\hline & & Mean & 0.866 & 0.753 & 0.004 & 5.817 \\
\hline \multirow{4}{*}{ Parabolic diffusion } & \multirow{4}{*}{$\mathrm{C}_{\mathrm{t}}=\mathrm{C}_{0}-\mathrm{kLn}_{\mathrm{t}}$} & 5 & 0.965 & 0.932 & 0.566 & 11.091 \\
\hline & & 25 & 0.892 & 0.796 & 0.447 & 5.593 \\
\hline & & 35 & 0.845 & 0.713 & 0.949 & 4.732 \\
\hline & & Mean & 0.901 & 0.814 & 0.654 & 7.139 \\
\hline \multirow{4}{*}{ Power function } & \multirow{4}{*}{$\mathrm{LnC}_{\mathrm{t}}=\mathrm{LnC}_{0}-\mathrm{kLn}_{\mathrm{t}}$} & 5 & 0.893 & 0.798 & 0.072 & 5.623 \\
\hline & & 25 & 0.931 & 0.866 & 0.027 & 7.177 \\
\hline & & 35 & 0.947 & 0.897 & 0.030 & 8.368 \\
\hline & & Mean & 0.923 & 0.854 & 0.043 & 7.056 \\
\hline \multirow{4}{*}{ Elovich } & \multirow{4}{*}{$\mathrm{C}_{\mathrm{t}}=\mathrm{C}_{0}-\mathrm{kLn}_{\mathrm{t}}$} & 5 & 0.903 & 0.815 & 0.913 & 5.934 \\
\hline & & 25 & 0.935 & 0.874 & 0.352 & 7.452 \\
\hline & & 35 & 0.949 & 0.900 & 0.474 & 8.487 \\
\hline & & Mean & 0.929 & 0.863 & 0.580 & 7.291 \\
\hline
\end{tabular}

Note. ${ }^{* *}$ significant at level 0.01 .

Elovich equation success in describing boron desorption corresponds to what Al-Falahi (2000) mentioned when he studied boron release kinetics in a number of soils from central and southern of Iraq. He pointed out that this equation can give a clear picture of the mechanism of boron releasing from these soils; boron release can be considered a complex function of heterogeneous surfaces, binding forces, chemical and physical nature of the reaction system. Al-Ameri (2013) also pointed to the superiority of Elovich equation and Power function in describing boron behavior with time in calcareous soil from central Iraq. These results are consistent with Peryea et al. (1985) when they found that Elovich equation succeeded in describing boron release data successfully in four soils from California. 
Table 3. Efficiency of kinetic and experimental equations in describing relationship between boron desorption and time $(\mathrm{n}=11)$ in Loamy soil

\begin{tabular}{|c|c|c|c|c|c|c|}
\hline Equation & Mathematical model & Temperature degree & $\mathrm{r}^{* *}$ & $\mathrm{r}^{2}$ & Standard error of estimate SE.e & t value \\
\hline \multirow{4}{*}{ Zero order } & \multirow{4}{*}{$\mathrm{C}_{\mathrm{t}}=\mathrm{C}_{0}-\mathrm{k}_{\mathrm{t}}$} & 5 & 0.880 & 0.774 & 0.945 & 5.559 \\
\hline & & 25 & 0.871 & 0.759 & 0.495 & 5.322 \\
\hline & & 35 & $0.710^{*}$ & 0.504 & 1.246 & 3.025 \\
\hline & & Mean & 0.820 & 0.679 & 0.895 & 4.635 \\
\hline \multirow{4}{*}{ First order } & \multirow{4}{*}{$\mathrm{LnC}_{\mathrm{t}}=\mathrm{LnC}_{0}-\mathrm{k}_{\mathrm{t}}$} & 5 & 0.891 & 0.793 & 0.056 & 5.876 \\
\hline & & 25 & 0.883 & 0.779 & 0.029 & 5.630 \\
\hline & & 35 & 0.747 & 0.558 & 0.072 & 3.372 \\
\hline & & Mean & 0.840 & 0.710 & 0.052 & 4.959 \\
\hline \multirow{4}{*}{ Second order } & \multirow{4}{*}{$1 / \mathrm{C}_{\mathrm{t}}=1 / \mathrm{C}_{0}+\mathrm{k}_{\mathrm{t}}$} & 5 & 0.898 & 0.806 & 0.003 & 6.108 \\
\hline & & 25 & 0.893 & 0.798 & 0.002 & 5.960 \\
\hline & & 35 & 0.782 & 0.611 & 0.004 & 3.763 \\
\hline & & Mean & 0.858 & 0.738 & 0.003 & 5.277 \\
\hline \multirow{4}{*}{ Parabolic diffusion } & \multirow{4}{*}{$\mathrm{C}_{\mathrm{t}}=\mathrm{C}_{0}-\mathrm{kLn}_{\mathrm{t}}$} & 5 & 0.935 & 0.874 & 0.708 & 7.887 \\
\hline & & 25 & 0.941 & 0.886 & 0.340 & 8.378 \\
\hline & & 35 & 0.783 & 0.613 & 1.102 & 3.772 \\
\hline & & Mean & 0.886 & 0.791 & 0.717 & 6.679 \\
\hline \multirow{4}{*}{ Power function } & \multirow{4}{*}{$\mathrm{LnC}_{\mathrm{t}}=\mathrm{LnC}_{0}-\mathrm{kLn}_{\mathrm{t}}$} & 5 & 0.810 & 0.656 & 0.067 & 3.902 \\
\hline & & 25 & 0.957 & 0.915 & 0.017 & 9.304 \\
\hline & & 35 & 0.897 & 0.805 & 0.040 & 5.755 \\
\hline & & Mean & 0.888 & 0.792 & 0.041 & 6.320 \\
\hline \multirow{4}{*}{ Elovich } & \multirow{4}{*}{$\mathrm{C}_{\mathrm{t}}=\mathrm{C}_{0}-\mathrm{kLn}_{\mathrm{t}}$} & 5 & 0.912 & 0.831 & 0.845 & 6.280 \\
\hline & & 25 & 0.960 & 0.923 & 0.261 & 9.798 \\
\hline & & 35 & 0.898 & 0.807 & 0.620 & 5.780 \\
\hline & & Mean & 0.923 & 0.854 & 0.575 & 7.286 \\
\hline
\end{tabular}

Note. ${ }^{* *}$ significant at level $0.01,{ }^{*}$ significant at level 0.05 .

Results showed (Table 5) that increase in the incubation temperature from 5 to $35^{\circ} \mathrm{C}$ increased boron release rate constant from 0.329 to $0.561 \mathrm{mg} \mathrm{kg}^{-1}$ hours ${ }^{-1}$ with increase of $70.5 \%$. The results showed a positive correlation between reaction temperature $(\mathrm{T})$ and boron release constant $(\mathrm{K})$ according to the simple linear regression equation: $\mathrm{K}=0.2827+7.4286 \times 10^{-3} \mathrm{~T}(\mathrm{r}=0.978)$. This equation shows that increasing reaction temperature one absolute degree led to an increase boron release rate constant by $7.4286 \times 10^{-3} \mathrm{mg} \mathrm{kg}^{-1}$ absolute degree. Increasing reaction temperature led to increases kinetic energy amount of the molecules, which increases the number of collisions between these molecules in time unit, which in turn increases molecules number that have energy equal to or greater than activation energy (Ea), which increases or Double desorption reactions speed (Bohn et al., 1985; Chang, 1977). 
Table 4. Efficiency of kinetic and experimental equations in describing relationship between boron desorption and time $(\mathrm{n}=11)$ in Sandy loam soil

\begin{tabular}{|c|c|c|c|c|c|c|}
\hline Equation & Mathematical model & Temperature degree & $\mathrm{r}^{* *}$ & $\mathrm{r}^{2}$ & Standard error of estimate S.Ee & t value \\
\hline \multirow{4}{*}{ Zero order } & \multirow{4}{*}{$\mathrm{C}_{\mathrm{t}}=\mathrm{C}_{0}-\mathrm{k}_{\mathrm{t}}$} & 5 & 0.753 & 0.567 & 1.335 & 3.431 \\
\hline & & 25 & 0.842 & 0.710 & 1.053 & 4.689 \\
\hline & & 35 & 0.849 & 0.721 & 1.184 & 4.825 \\
\hline & & Mean & 0.815 & 0.666 & 1.191 & 4.315 \\
\hline \multirow{4}{*}{ First order } & \multirow{4}{*}{$\operatorname{LnC}_{\mathrm{t}}=\mathrm{LnC}_{0}-\mathrm{k}_{\mathrm{t}}$} & 5 & 0.783 & 0.613 & 0.077 & 3.772 \\
\hline & & 25 & 0.865 & 0.748 & 0.067 & 5.174 \\
\hline & & 35 & 0.879 & 0.773 & 0.067 & 5.534 \\
\hline & & Mean & 0.842 & 0.711 & 0.070 & 4.827 \\
\hline \multirow{4}{*}{ Second order } & \multirow{4}{*}{$1 / \mathrm{C}_{\mathrm{t}}=1 / \mathrm{C}_{0}+\mathrm{k}_{\mathrm{t}}$} & 5 & 0.810 & 0.657 & 0.005 & 4.151 \\
\hline & & 25 & 0.886 & 0.786 & 0.004 & 5.745 \\
\hline & & 35 & 0.906 & 0.821 & 0.004 & 6.418 \\
\hline & & Mean & 0.867 & 0.755 & 0.004 & 5.438 \\
\hline \multirow{4}{*}{ Parabolic diffusion } & \multirow{4}{*}{$\mathrm{C}_{\mathrm{t}}=\mathrm{C}_{0}-\mathrm{kLn}_{\mathrm{t}}$} & 5 & 0.853 & 0.727 & 1.059 & 4.901 \\
\hline & & 25 & 0.971 & 0.942 & 2.441 & 11.423 \\
\hline & & 35 & 0.926 & 0.858 & 0.845 & 7.372 \\
\hline & & Mean & 0.917 & 0.842 & 1.448 & 7.899 \\
\hline \multirow{4}{*}{ Power function } & \multirow{4}{*}{$\mathrm{LnC}_{\mathrm{t}}=\mathrm{LnC}_{0}-\mathrm{kLn}_{\mathrm{t}}$} & 5 & 0.967 & 0.936 & 0.028 & 10.808 \\
\hline & & 25 & 0.980 & 0.960 & 0.027 & 13.931 \\
\hline & & 35 & 0.966 & 0.934 & 0.035 & 10.609 \\
\hline & & Mean & 0.971 & 0.943 & 0.030 & 11.783 \\
\hline \multirow{4}{*}{ Elovich } & \multirow{4}{*}{$\mathrm{C}_{\mathrm{t}}=\mathrm{C}_{0}-\mathrm{kLn}_{\mathrm{t}}$} & 5 & 0.968 & 0.936 & 0.441 & 10.825 \\
\hline & & 25 & 0.983 & 0.965 & 0.358 & 14.958 \\
\hline & & 35 & 0.971 & 0.943 & 0.504 & 11.518 \\
\hline & & Mean & 0.974 & 0.948 & 0.434 & 12.434 \\
\hline
\end{tabular}

Note. ${ }^{* *}$ significant at level 0.01 .

Number of studies have indicated temperature effect on the speed and path of boron release rate constant (K), Goldberg et al. (1993) pointed out that Boron adsorption decreased with increasing temperature from 10 to $40{ }^{\circ} \mathrm{C}$, Al-Falahi (2000) mentioned that boron releases increased with the increasing of temperature when he studied status and behavior of boron in Iraqi soil, Al-Ameri (2013) pointed out B concentrations increased with temperature. 

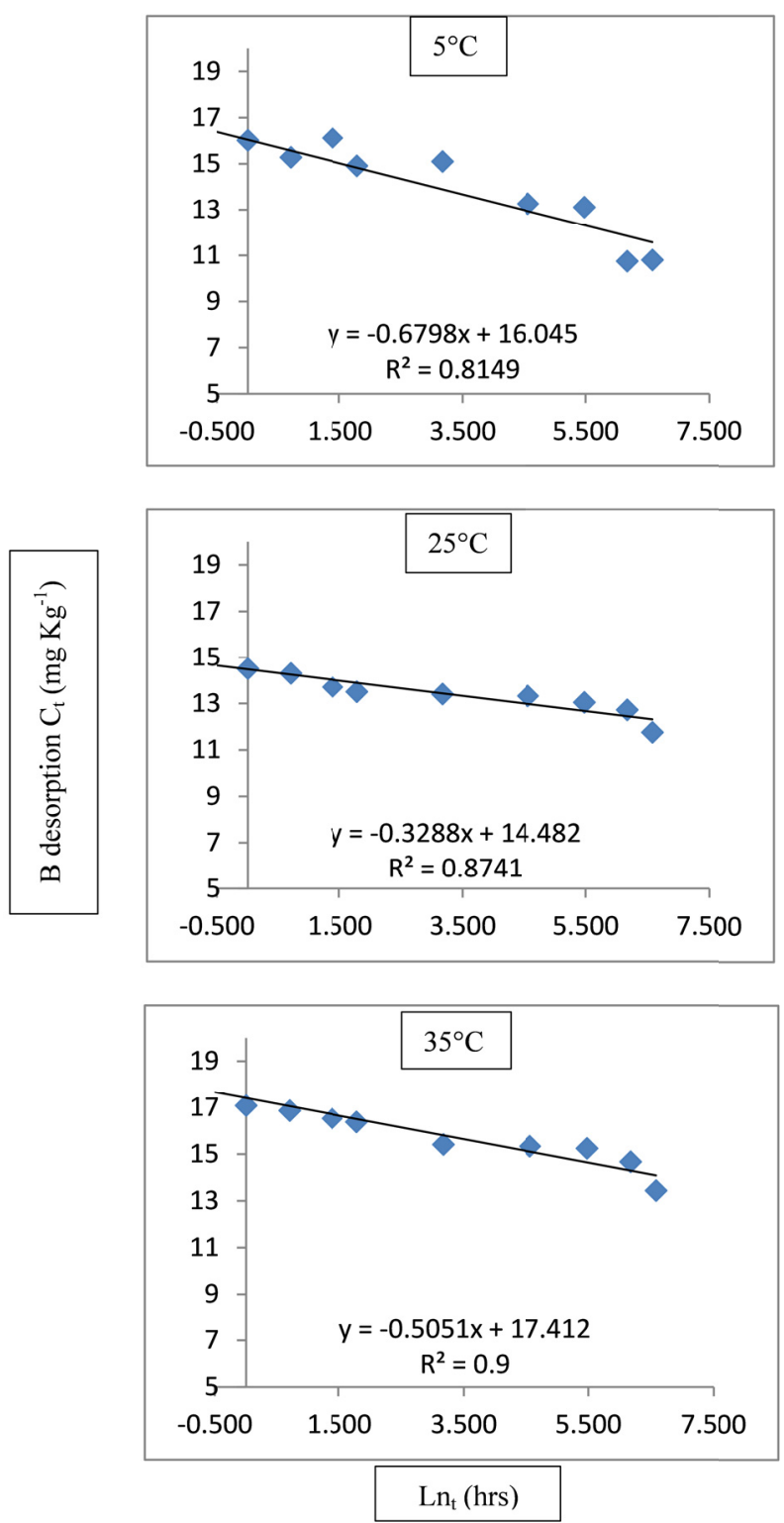

Figure 1. Relationship between boron desorption $\mathrm{C}_{\mathrm{t}}\left(\mathrm{mg} \mathrm{Kg}^{-1}\right)$ with time $\mathrm{Ln}_{\mathrm{t}}$ (hrs.) according to Elovich equation in clay soil 

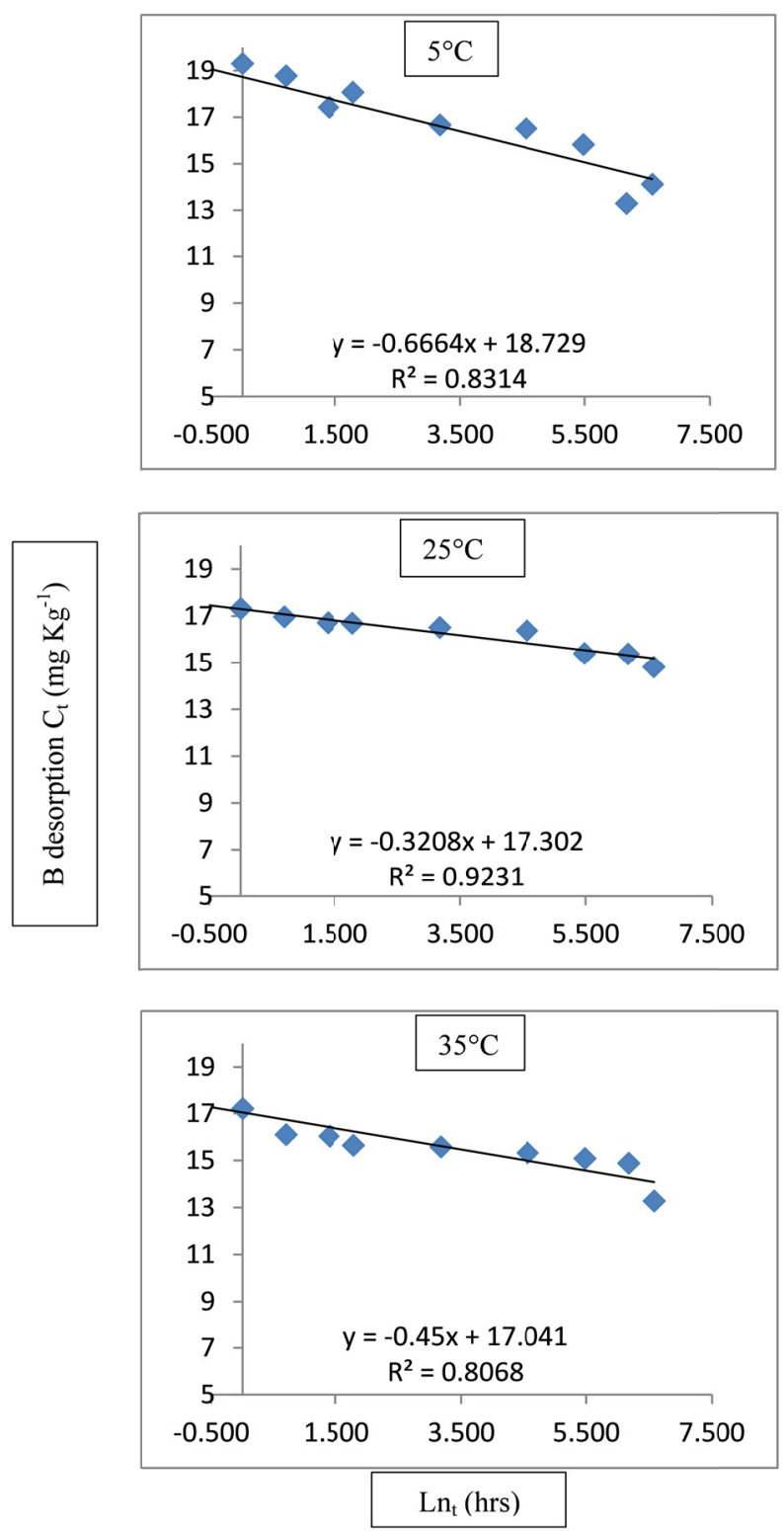

Figure 2. Relationship between boron desorption $\mathrm{C}_{\mathrm{t}}\left(\mathrm{mg} \mathrm{Kg}^{-1}\right)$ with time $\mathrm{Ln}_{\mathrm{t}}$ (hrs.) according to Elovich equation in loam soil 


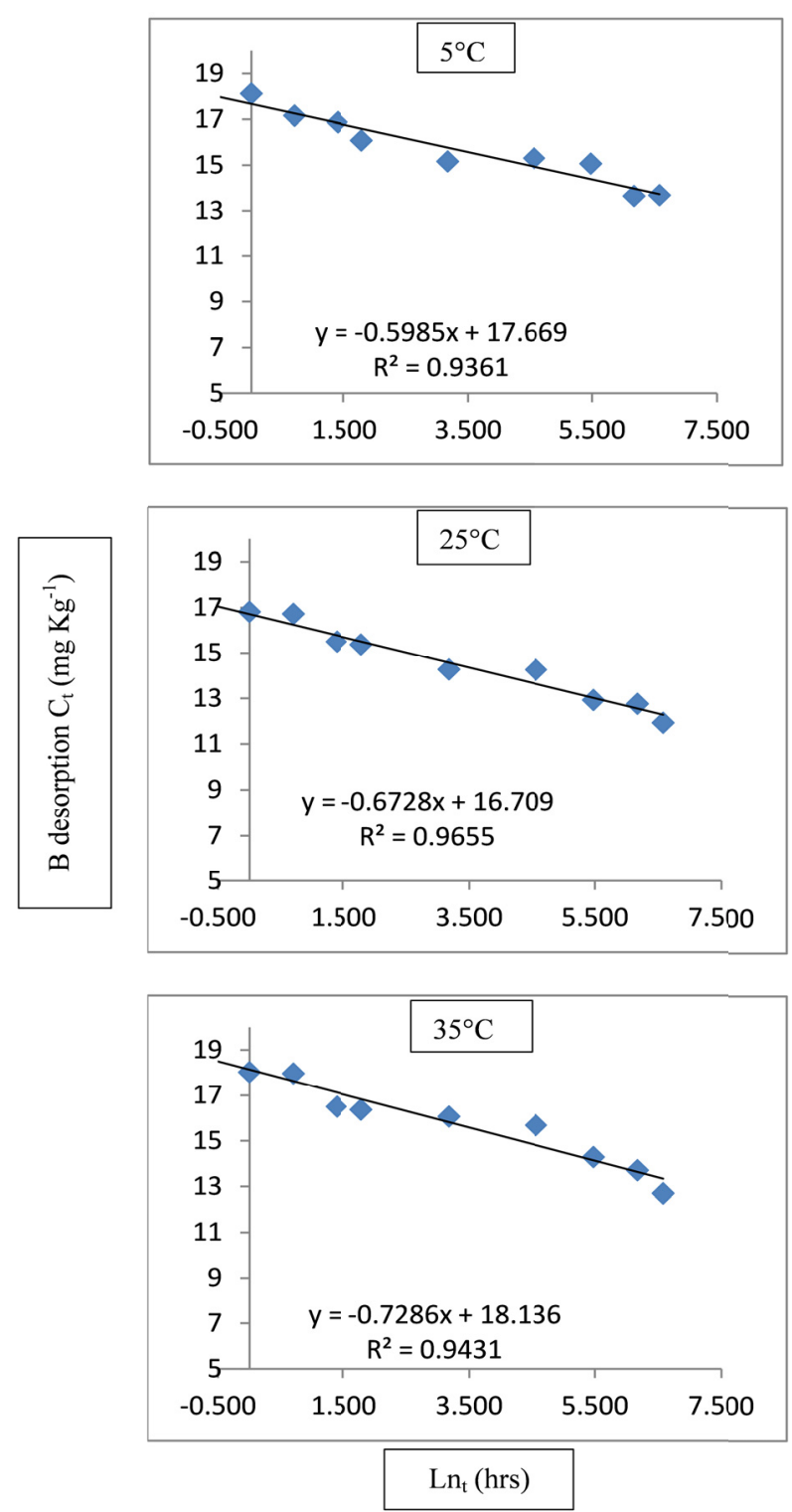

Figure 3. Relationship between boron desorption $\mathrm{C}_{\mathrm{t}}\left(\mathrm{mg} \mathrm{Kg}^{-1}\right)$ with time $\mathrm{Ln}_{\mathrm{t}}(\mathrm{hrs}$.) according to Elovich equation in sandy loam soil

Table 5. Release rate constant and activation energy of boron at different incubation temperatures and for all incubation periods

\begin{tabular}{|c|c|c|c|c|c|}
\hline \multirow{3}{*}{ Soil } & \multicolumn{3}{|c|}{$\mathrm{K}$ release rate $\mathrm{B}\left(\mathrm{mg} \mathrm{Kg}^{-1}\right.$ hours $\left.^{-1}\right)$} & \multirow{3}{*}{ Mean } & \multirow{3}{*}{$\begin{array}{l}\text { Activation energy } \\
\left(\mathrm{Ea} \mathrm{KJ} \mathrm{mol}^{-1}\right)\end{array}$} \\
\hline & \multicolumn{3}{|c|}{ Incubation temperature } & & \\
\hline & 5 & 25 & 35 & & \\
\hline Clay & 0.202 & 0.329 & 0.505 & 0.345 & 20.923 \\
\hline Loam & 0.188 & 0.321 & 0.450 & 0.320 & 20.332 \\
\hline Sandy loam & 0.598 & 0.673 & 0.729 & 0.667 & 4.596 \\
\hline Mean & 0.329 & 0.441 & 0.561 & 0.444 & 15.284 \\
\hline
\end{tabular}

Soil texture was found to have an effect on the path and boron release rate constant $(\mathrm{K})$, as indicated by the results shown in Table 5. The highest mean of boron release rate constant for all temperatures and incubation periods was in sandy loam soil. The mean release constant for this element was $0.345,0.320$ and $0.667 \mathrm{mg} \mathrm{B}$ $\mathrm{kg}^{-1} \mathrm{hrs}^{-1}$ for clay, loam and sandy loam respectively. Average boron release rate constant in sandy loam soil compared to clay and loam soil was increased due to the chemical and physical soil properties. The low clay 
content and electrical conductivity (Table 1) have contributed the faster release of this element and increase of its diffusion coefficient from solid phase to liquid phase (soil solution) compared to clay and loamy soil. This is consistent with several studies that indicated increased boron release by low clay content and electrical conductivity as indicated by Nicholaichuk et al. (1988) that Boron adsorption maxima increased with increasing clay content, Awad and Maki (1990) showed that highest values of adsorption maximum recorded in fine textured soils in another study on calcareous soils of Iraq, soils low in clay adsorb less boron than clay-rich soils (Keren, 1996).

Activation energy of boron release in the three soils was calculated according to the Arrhenius equation (Chang, 1977): $\mathrm{LnK}=\mathrm{LnA}-\mathrm{Ea} / \mathrm{R}(1 / \mathrm{T})$. This equation shows linear relationship between the boron release rate constant $(\mathrm{K})$ and inverted absolute temperature $(1 / \mathrm{T})$ there is a positive correlation between $\mathrm{K}$ and absolute temperature.

The results indicated the effect of soils under study in boron release activation energy (Table 5). The overall average of boron release activation energy of three soils was 15.284 and the highest was 20.923 in clay soil and the lowest amount was 4.596 in sandy loam while loamy soil gave $20.332 \mathrm{KJ} \mathrm{mol}^{-1}$. Boron release activation energy in clay soil increased by 2.9 and $355.2 \%$ compared to its value in loam and sandy loam soil, respectively. This is due to the high clay and organic matter content, low electrical conductivity values which leads to fact that boron is susceptible to rapid reactions such as retention (adsorption and precipitation) on clay and organic matter surfaces as well as formation complexes with dominant ions in soil which contributed in reducing boron release rate constant in those soils compared to sandy loam soil, this is confirmed by many studies Havlin et al. (2005), Goldberg et al. (1996) and Yermiyaho et al. (1995) which indicated that boron release decreases with increasing clay and organic matter content, low electrical conductivity, this means activation energy for boron release reaction is high as a result.

Boron fertilizer release constant increased by a decrease in activation energy Ea (Table 5). Therefore, soil properties, such as clay and silt content, which contribute to reduction boron release rate constant, increase activation energy, thus reducing its availability. These results are consistent with the finding of Havlin et al. (2005) that plants can take larger amounts of boron from coarse texture compared with fine textured soils at equal concentrations of boron dissolved in water.

\section{Conclusion}

The Soils vary in their capacity to release boron and in activation energy (Ea) which are affecting by temperature, time and clay content. Elovich equation successfully describes boron release kinetics of three soils. It is clear from this study that a large proportion of added boron is subject to rapid release from loam and sandy loam soil due to their low content of clay and organic matter.Therefore, it is necessary to take advantage of the kinetic chemistry concepts in describing boron behavior in management boron fertilizers.

\section{References}

Al-Ameri, B. H. (2001). Behavior and Efficiency of Some Zinc Fertilizers in Calcareous Soils (MSc. thesis, University of Baghdad, Agriculture College).

Al-Ameri, B. H. (2013). Behavior, Availability, and FUE of Zn-DTPA and $\mathrm{H}_{3} \mathrm{BO}_{3}$ in Soil and Their Effect on Maize (Zea mays L.) Productivity ( $\mathrm{PhD}$ thesis, University of Baghdad, Agriculture College).

Al-Falahi, A. A. (2000). Status and Behavior of Boron in Iraqi Saline Soils (PhD thesis, University of Baghdad, Agriculture College).

Awad, K. M., \& Maki, A. K. (1990). Boron adsorption by calcareous soils as related to soil properties. Mesopotamia J. Agric., 22(4), 45-56.

Berger, K. C., \& Troug, E. (1939). Boron deficiencies as revealed by plants and soil tests. J. Am. Soc. Agron, 32, 297-301. https://doi.org/10.2134/agronj1940.00021962003200040007x

Bohn, H. L., Mcneal, B. L., \& O’Connor, G. A. (1985). Soil Chemistry. John Wiely \& Sons, N. Y.

Chang, R. (977). Physical Chemistry with Application to Biological System. Macmillan Pub. Co., Inc., N. Y.

Chien, S. H., Clayton, W. R., \& McClellan, G. H. (1980). Kinetics of dissolution of phosphate rocks in soils. Soil Sci. Am. J., 44, 260-264. https://doi.org/10.2136/sssaj1980.03615995004400020012x

Fried, M., \& Broeshart, H. (1967). The Soil-Plant System in relation to Inorganic Nutrition. Academic Press, NY.

Goldberg, S., Forster, H. S., \& Heick, E. L. (1993). Temperature effects on boron adsorption by reference minerals and soils. Soil Sci, 156, 316-321. https://doi.org/10.1097/00010694-199311000-00004 
Goldberg, S., Forster, H. S., Lesch, S. M., \& Heick, E. L. (1996). Influence of anion competition on boron adsorption by clays and soils. Soil Science, 161(2), 99-103. https://doi.org/10.1097/00010694-19960200000003

Havlin, J. L., Beaton, J. D., Tisdal, S. L., \& Nelson, W. L. (2005). Soil Fertility and Fertilizers (7th ed.). An introduction to nutrient management. Upper Saddle River, New Jersey.

Keren, R. (1996). Boron. In D. L. Sparks (Ed.), Methods of Soil Analysis (Part 3., pp. 603-626). Chemical Methods. SSSA Book Series 5, Madison.

Nicholaichuk, W., Leyshon, A. J., Jame, Y. W., \& Campbell, C. A. (1988). Boron and salinity survey of irrigation projects and the boron adsorption characteristics of some Saskatchewan soils. Can. J. Soil Sci., 68, 77-90. https://doi.org/10.4141/cjss88-007

Page, A. L., Miller, R. H., \& Kenney, D. R. (1982). Part 2: Chemical and Microbiological Properties. Methods of soil analysis. Am. Soc. Agron. Madison, Wis.

Peryea, F. J., Bingham, F. T., \& Rhoads, J. D. (1985). Kinetics of post-reclamation boron dissolution. Soil Sci. Soc. Am. J., 49, 836-839. https://doi.org/10.2136/sssaj1985.03615995004900040009x

Sparks, D. L. (1986). Kinetics of reaction in pure and mixed systems. In D. L. Sparks (Ed.), Soil Physical Chemistry (pp. 83-145).

Yermiyaho, U., Keren, R., \& Chen, Y. (1995). Boron sorption by soil in the presence of composted organic matter. Soil Sci. Soc. Amer. J., 59, 405-409. https://doi.org/10.2136/sssaj1995.03615995005900020019x

\section{Copyrights}

Copyright for this article is retained by the author(s), with first publication rights granted to the journal.

This is an open-access article distributed under the terms and conditions of the Creative Commons Attribution license (http://creativecommons.org/licenses/by/4.0/). 